\title{
Peranan Penyuluh Pertanian Dalam Pengembangan Kelompok Tani Di Desa Sungai Binuang Kecamatan Haur Gading Kabupaten Hulu Sungai Utara
}

\section{(Role of Agricultural Extension in Development Of Farmers in Binuang Village Haur Gading District Hulu Sungai Utara Regency)}

\author{
Azwar Saihani $^{1)}$ \& Siti Noor Asiah Jamil ${ }^{2)}$ \\ Program Studi Agribisnis, Sekolah Tinggi Ilmu Pertanian Amuntai \\ 1)Azwar.saihani63@yahoo.com \\ 2)jamilasiah@yahoo.com
}

\begin{abstract}
ABSTRAK
Penelitian ini bertujuan untuk mengidentifikasi peran penyuluh dalam pengembangan kelompok tani di Desa Sungai Binuang Kecamatan Haur Gading, serta bagaimana kewenangan dan kompetensi penyuluh terhadap kelompok tani saat ini. Penelitian ini dilakukan di Desa Sungai Binuang Kecamatan Haur Gading pada Bulan Maret-Mei 2016. Sampel yang diambil dalam penelitian ini seluruh anggota kelompok tani yang ada di Desa Sungai Binuang. Metode analisa yang digunakan dalam penelitian ini adalah analisa deskriptif dan skala likert untuk pengukuran indikatornya. peran penyuluh sebagai pembimbing petani yaitu berada pada angka rata-rata 287 pada kategori interval baik dengan angka 76,5\% tergolong kuat, sebagai organisator dan dinamisator penyuluh berada pada angka rata-rata 306 pada daerah sangat baik dengan 81,6\% tergolong sangat kuat, sebagai teknisi penyuluh memiliki rata-rata angka 306 pada daerah sangat baik dan 81,6\% tergolong sangat kuat, serta penyuluh sebagai konsultan petani yaitu pada angka 306,5 berada pada daerah sangat baik dan secara kontinum 81,7\% pada interval sangat kuat. Dari hasil penelitian diperoleh bahwa peranan penyuluh pertanian di Desa Sungai Binuang sudah berjalan cukup optimal. Kewenangan dan kompetensi penyuluh pertanian belum bisa dilakukan secara optimal karena seorang penyuluh pertanian hanya berwenang mengarahkan dan memberi masukan atas segala keputusan yang diambil dalam suatu kelompok.
\end{abstract}

Kata kunci : Peran, penyuluh, kelompok tani, pembimbing, konsultan.

\begin{abstract}
This study aims to identify the role of extension agents in developing farmer groups in Sungai Binuang Village, Haur Gading District, as well as how the current authority and competence of extension agents to farmer groups. This research was conducted in Sungai Binuang Village, Haur Gading SubDistrict in March-May 2016. The samples taken in this study were all members offarmer groups in Sungai Binuang Village. The analysis method used in this study is descriptive analysis and Likert scale for measuring indicators. the role of extension agents as farmer supervisors is at an average number of 287 in the good interval category with a number of $76.5 \%$ classified as strong, as an organizer and dynamist the instructor is at an average rate of 306 in a very good area with $81.6 \%$ classified as very strong, as a technician the extension has an average number of 306 in the area is very good and $81.6 \%$ is classified as very strong, and the extension agent as a farmer consultant that is 306.5 in the area very well and continuum $81.7 \%$ at very strong intervals. From the results of the study, it was found that the role of agricultural extension agents in Sungai Binuang Village was already quite optimal. The authority and competence of agricultural extension agents cannot be done optimally because an agricultural instructor is only authorized to direct and provide input on all decisions taken in a group.
\end{abstract}

Keywords: Roles, extension agents, farmer groups, mentors, consultants.

\section{PENDAHULUAN}

Kegiatan penyuluhan dalam pembangunan pertanian berperan sebagai jembatan yang menghubungkan antara praktek yang dijalankan oleh petani dengan pengetahuan dan teknologi petani yang selalu berkembang menjadi kebutuhan para petani tersebut. Agar petani dapat melakukan praktek-praktek yang mendukung usaha tani maka petani membutuhkan informasi inovasi dibidang pertanian. Informasi tersebut dapat diperoleh petani antara lain dari PPL (Penyuluh Pertanian Lapang) melalui 
penyelenggaraan kegiatan penyuluhan pertanian. Tujuan penyuluhan adalah terjadinya perubahan peilaku sasarannya. Sejalan Begitu pula dengan program program penyuluhan pertanian yang selama ini sudah berjalan, belum mampu secara optimal membantu petani dalam meningkatkan taraf hidupnya, serta belum mampu mendorong petani untuk menemukan pemecahan masalahnya sendiri dalam melaksanakan usaha taninya (Mushero, 2008).

Pengertian penyuluhan menurut Setiana (2005), adalah ilmu sosial yang mempelajari sistem dan proses perubahan pada individu serta masyarakat agar dapat terwujud perubahan yang lebih baik sesuai dengan yang diharapkan. Penyuluhan, dengan demikian dapat diartikan sebagai suatu sistem pendidikan yang bersifat nonformal diluar sistem sekolah yang biasa. Menurut Hawkins (1999), penyuluhan merupakan keterlibatan seseorang untuk melakukan komunikasi informasi secara sadar dengan tujuan membantu sesamanya memberikan pendapat sehingga bias membuat keputusan yang benar. Pendidikan penyuluhan adalah ilmu yang berorientasi keputusan tetapi juga berlaku pada ilmu sosial berorientasi pada kesimpulan. Ilmu ini mendukung keputusan strategis yang harus diambil dalam organisasi penyuluhan. Penyuluhan juga dapat menjadi sarana kebijaksanaan yang efektif untuk mendorong pembangunan pertanian dalam situasi petani tidak mampu mencapai tujuannya karena keterbatasan pengetahuan dan wawasan. Sebagai sarana kebijakan, hanya jika sejalan dengan kepentingan pemerintah atau organisasi yang mendanai jasa penyuluhan guna mencapai tujuan petani.

Kegiatan penyuluhan pertanian melibatkan dua kelompok yang aktif. Disatu pihak adalah kelompok penyuluh dan yang kedua adalah kelompok yang disuluh. Penyuluh adalah kelompok yang diharapkan mampu membawa sasaran penyuluhan pertanian kepada cita-cita yang telah digariskan, sedangkan yang disuluh adalah kelompok yang diharapkan mampu menerima paket penyuluhan pertanian (Sastraatmadja, 1993).
Penyuluhan sebagai proses pemberdayaan masyarakat, merupakan proses pemandirian masyarakat. Pemandirian bukanlah menggurui, melainkan mensyaratkan tumbuh dan berkembangnya partisipasi atau peran serta secara aktif dari semua pihak yang akan menerima manfaat penyuluhan, terutama masyarakat petani sendiri (Mardikanto, 2009). Salah satu program pemerintah dalam pemberdayaan petani yaitu melalui Kelompok Tani.

Sungai Binuang adalah salah satu dari 18 desa di Kecamatan Haur Gading Kabupaten Hulu Sungai Utara dengan jumlah penduduk yang banyak dan sebagian besar masyarakat dengan profesi petani dan pengrajin. Di Desa Sungai Binuang telah dibentuk 3 kelompok tani dengan nama Gapoktan Sungai Binuang dibimbing oleh penyuluh pembina Khasuna Ridha dengan total seluruh anggota 75 anggota dengan masing-masing kelompok memiliki nama diantaranya "Matang Sawo, Manalagi dan Nusa indah" dengan tingkat kemampuan kelompok lanjut. Komoditas unggulan dari desa Sungai Binuang adalah tanaman padi dan terdapat sebagian kecil perkebunan karet. Dalam menghadapi permasalahan petani sering memutuskan sesuatu berdasarkan kepentingannya, tetapi ada saatnya dimana penyuluh perlu mengambil keputusan demi kepentingan petani.

Dari data desa di Kecamatan Haur Gading yang secara morfologi memiliki 18 desa dengan 18 gapoktan dengan masingmasing desa memiliki kelompok tani dengan anggota yang berbeda-beda dan tahun pembentukan yang berbeda. Salah satu faktor yang mempengaruhi tingkat perkembang-an kelompok tani adalah terlaksananya peran penyuluh pertanian dengan baik. Namun dalam pengembangan kelompok tani khususnya di Desa Sungai Binuang tidak selalu berjalan dengan baik masih terdapat hambatan yang dihadapi dalam pengembangan Kelompok tani. Untuk itu diperlukan suatu kajian yang mendalam mengenai peran penyuluh pertanian dalam pengembangan Kelompok Tani di Desa Sungai Binuang Kecamatan Haur Gading Kabupaten Hulu Sungai Utara 
(Balai Penyuluhan Kecamatan Haur Gading Kabupaten Hulu Sungai Utara, 2013).

Penelitian ini bertujuan mengkaji peranan penyuluh pertanian dalam pengembangan Kelompok Tani serta menjelaskan kewenangan dan kompetensi yang dimiliki oleh penyuluh pada kelompok tani di Desa Sungai Binuang Kecamatan Haur Gading.

\section{METODE PENELITIAN}

\section{Lokasi dan Waktu Penelitian}

Penelitian ini dilaksanakan di Desa Sungai Binuang kecamatan Haur Gading Kabupaten Hulu Sungai Utara Provinsi Kalimantan Selatan. Penelitian dilakukan mulai bulan Maret-Mei 2016 mulai tahap persiapan, pengumpulan data, pengolahan data sampai penulisan laporan.

\section{Jenis dan Sumber Data}

Jenis data yang digunakan adalah Deskriptif dan sumber data dengan study pustaka yang digunakan dalam penelitian ini adalah data primer dan data sekunder. Data primer diperoleh dengan cara mengadakan wawancara langsung dengan kelompok tani responden dengan menggunakan daftar

\section{HASIL DAN PEMBAHASAN}

\section{Peran Penyuluh}

pertanyaan yang telah dipersiapkan sebelumnya. Sedangkan data sekunder adalah data yang diperoleh dari dinas atau instansi lain yang terkait

\section{Analisis Data}

Analisis deskriptif digunakan untuk mengidentifikasi persepsi kelompok tani terhadap peran penyuluh melalui pengisian kuesioner. Hasil dari analisis tersebut diberikan skala atau nilai. Skala Likert digunakan untuk mengukur sikap, pendapat dan persepsi seseorang atau sekelompok orang tentang peranan penyuluh pertanian dalam pengembangan kelompok tani di desa Sungai Binuang Kecamatan Haur Gading, fenomena sosial ini telah ditetapkan secara spesifik oleh peneliti sebagai variabel penelitian. Skala itu sendiri salah satu artinya, sekedar memudahkan, adalah ukuran-ukuran berjenjang. Skala penilaian, misalnya, merupakan skala untuk menilai sesuatu yang pilihannya berjenjang, misalnya $0,1,2,3,4,5,6,7,8,9,10$. Skala Likert juga merupakan alat untuk mengukur (mengumpulkan data dengan cara "mengukur - menimbang") yang “itemnya"(butir-butir pertanyaannya) berisikan pilihan yang berjenjang.

\subsection{Penyuluh Sebagai Pembimbing}

Dari hasil penelitian diperoleh tanggapan responden atas peranan penyuluh pertanian sebagai pembimbing sebagai berikut :

Tabel 1. Tanggapan responden terhadap peran penyuluh sebagai pembimbing.

\begin{tabular}{|c|c|c|c|c|c|c|}
\hline \multirow{2}{*}{$\begin{array}{c}\text { Nomor } \\
\text { Pertanyaan }\end{array}$} & \multicolumn{5}{|c|}{ Frekuensi Skor } & \multirow{2}{*}{$\begin{array}{c}\text { Jumlah responden } \\
\text { x nilai skor }\end{array}$} \\
\hline & 5 & 4 & 3 & 2 & 1 & \\
\hline 1 & 22 & 39 & 10 & 4 & 0 & 304 \\
\hline 2 & 4 & 24 & 34 & 11 & 2 & 242 \\
\hline 3 & 12 & 55 & 8 & 0 & 0 & 304 \\
\hline 4 & 10 & 54 & 10 & 1 & 0 & 298 \\
\hline jumlah & 48 & 172 & 62 & 16 & 2 & 1.148 \\
\hline \multicolumn{6}{|c|}{ Rata-rata } & 287 \\
\hline
\end{tabular}

Sumber : Data Primer (2016).

Berdasarkan tabel diatas diketahui frekuensi tertinggi terhadap peran penyuluh sebagai pembimbing berada pada skor 4 dengan keterangan setuju pada jumlah skor 1.148 dengan nilai rata-rata 287 maka dapat diketahui peran penyuluh sebagai pembimbing lebih mendekati kategori interval setuju. 
Jumlah skor ideal dari 4 pertanyaan $=$ $5 \times 75=375$ (SS)

Jumlah skor terendah $=1 \times 75=75($ STS $)$
Berdasarkan data yang diperoleh dari 75 responden maka peran penyuluh sebagai pembimbing secara kontinum dapat dilihat seperti :


Berdasarkan skala Likert di atas, diperoleh peran penyuluh sebagai pembimbing berdasarkan data yang diperoleh dari 75 responden, yang menyatakan setuju terhadap peran penyuluh dalam memberikan bimbingan dengan adalah 55 responden, 39 responden yang menyatakan setuju terhadap pembinaan teknik usaha, 24 responden yang menyatakan setuju terhadap tanggapan pelaksanaan penyuluh 1 kali dalam sebulan, dan 54 responden yang menyatakan setuju terhadap bimbingan informasi saprodi. Hal ini disebabkan karena para penyuluh di Desa Sungai Binuang bersikap profesional yang selalu memberikan pembinaan kepada petani dari pengalaman hidup maupun secara teoritis. Di Desa Sungai Binuang pertemuan kelompok tidak selalu dilaksanakan 1 kali dalam sebulan tetapi pelaksanaan pertemuan kelompok bisa 1 kali dalam dua bulan dan dirasa kurang optimal oleh kelompok tani karena minimnya kegiatan pertemuan dengan penyuluh.

Peran penyuluh pertanian dalam mengusahakan bantuan modal dan memberi informasi mengenai sumber dana kredit sudah optimal, upaya penyuluh dalam merekomendasikan kelompok agar bisa mendapatkan bantuan dari dinas pertanian. Dilihat dari keseluruhan tanggapan dari beberapa responden anggota kelompok, maka peran penyuluh pertanian di Desa Sungai Binuang cukup baik karena penyuluh dirasa telah cukup optimal dalam memenuhi perannya sebagai pembimbing.

\subsection{Penyuluh sebagai Organisator dan Dinamisator}

Dari hasil penelitian dapat diketahui tanggapan responden mengenai peran penyuluh sebagai organisator dan dinamisator sebagai berikut :

Tabel 2. Tanggapan responden terhadap peran penyuluh sebagai organisator dan dinamisator.

\begin{tabular}{|c|c|c|c|c|c|c|}
\hline \multirow{2}{*}{$\begin{array}{c}\text { Nomor } \\
\text { Pertanyaan }\end{array}$} & \multicolumn{5}{|c|}{ Frekuensi Skor } & \multirow{2}{*}{$\begin{array}{c}\text { Jumlah responden } \\
\text { x nilai skor }\end{array}$} \\
\hline & 5 & 4 & 3 & 2 & 1 & \\
\hline 1 & 20 & 48 & 7 & 0 & 0 & 313 \\
\hline 2 & 26 & 44 & 5 & 0 & 0 & 321 \\
\hline 3 & 24 & 38 & 12 & 1 & 0 & 310 \\
\hline 4 & 16 & 26 & 27 & 6 & 0 & 280 \\
\hline jumlah & 86 & 156 & 51 & 7 & 0 & 1.224 \\
\hline \multicolumn{6}{|c|}{ Rata-rata } & 306 \\
\hline
\end{tabular}

Sumber : Data Primer (2016).

Berdasarkan tabel diatas diketahui frekuensi tertinggi terhadap peran penyuluh sebagai organisator dan dinamisator berada pada skor 4 dengan keterangan setuju pada jumlah skor 1.224 dengan nilai rata-rata 306 maka dapat diketahui peran penyuluh sebagai organisator dan dinamisator berada pada daerah sangat setuju.

Jumlah skor ideal dari 4 pertanyaan $=$ $5 \times 75=375$ (SS)

Jumlah skor terendah

$=1 \times 75=75($ STS $)$ 
Berdasarkan data yang diperoleh dari 75 responden maka peran penyuluh sebagai organisator dan dinamisator secara kontinum dapat dilihat seperti :

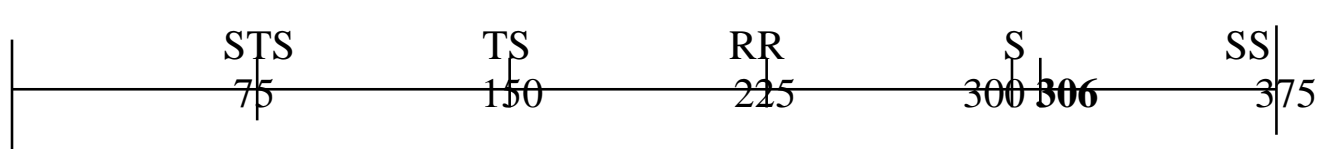

Jadi berdasarkan data di atas yang diperoleh dari 75 responden maka peran penyuluh sebagai organisator dan dinamisator yaitu $306 / 375 \times 100 \%=81,6 \%$ tergolong interval sangat kuat. Persentase kelompok responden dapat dilihat seperti :

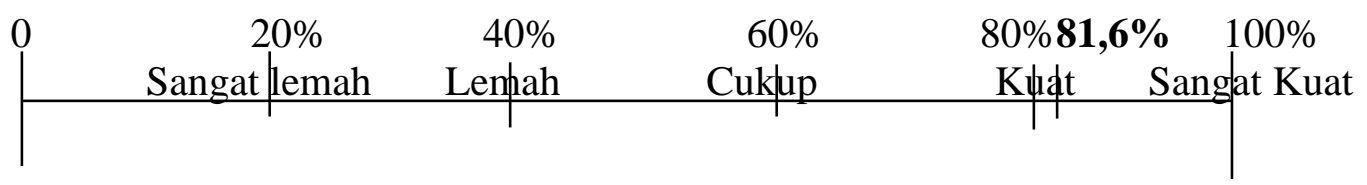

Berdasarkan skala Likert di atas, diperoleh peran penyuluh sebagai organisator dan dinamisator berdasarkan data yang diperoleh dari 75 responden berada pada nilai tertinggi yang setuju terhadap peran penyuluh dalam pengembangan kelompok dengan jumlah 48 responden yang menyatakan setuju. 44 responden yang menyatakan setuju terhadap pemberian solusi dan masalah pertanian, 38 responden yang menyatakan setuju terhadap tanggapan pengambilan keputusan dikelompok tani, dan 26 responden yang menyatakan setuju terhadap persensi kunjungan penyuluh yang tidak dilaksanakan 1 kali dalam sebulan. Peran penyuluh sebagai organisator dan dinamisator sudah banyak menghidupkan kembali kelompok-kelompok yang sempat vakum hingga berjalan aktif kembali. Penyuluh sering memberi masukan tentang masalah kegiatan usahatani dilapangan yang sering ditemui petani serta informasi lainnya mengenai usahatani.

Penyuluh pertanian juga berperan dalam pengambilan keputusan disuatu kelompok dengan cara musyawarah mufakat, namun seorang penyuluh hanya bertindak sebagai pengarah dalam kelompok sedangkan keputusan sepenuhnya mutlak ditangan kelompok. Persensi kunjungan penyuluh kurang optimal, hal ini dibuktikan dengan kehadiran penyuluh dalam suatu kegiatan rutin pertemuan kelompok meskipun terkadang pertemuan kelompok dilaksanakan 1 kali dalam dua bulan.

\subsection{Penyuluh sebagai Teknisi}

Berikut ini adalah data hasil penelitian mengenai tanggapan responden tentang peranan penyuluh sebagai teknisi.

Tabel 3. Tanggapan responden terhadap peran penyuluh sebagai teknisi.

\begin{tabular}{|c|c|c|c|c|c|c|}
\hline \multirow{2}{*}{$\begin{array}{c}\text { Nomor } \\
\text { Pertanyaan }\end{array}$} & \multicolumn{5}{|c|}{ Frekuensi Skor } & \multirow{2}{*}{$\begin{array}{c}\text { Jumlah responden } \\
\text { x nilai skor }\end{array}$} \\
\hline & 5 & 4 & 3 & 2 & 1 & \\
\hline 1 & 26 & 37 & 11 & 1 & 0 & 313 \\
\hline 2 & 19 & 40 & 12 & 4 & 0 & 299 \\
\hline jumlah & 45 & 77 & 23 & 5 & 0 & 612 \\
\hline \multicolumn{6}{|c|}{ Rata-rata } & 306 \\
\hline
\end{tabular}

Sumber : Data Primer (2016).

Berdasarkan tabel diatas diketahui frekuensi tertinggi terhadap peran penyuluh sebagai teknisi berada pada skor 4 dengan keterangan setuju pada jumlah skor 612 dengan nilai rata-rata 306 maka dapat diketahui peran penyuluh sebagai teknisi berada pada daerah sangat setuju.

Jumlah skor ideal dari 2 pertanyaan = $5 \times 75=375$ (SS)

Jumlah skor terendah

$=1 \times 75=75$ (STS) 
Berdasarkan data yang diperoleh dari 75 responden maka peran penyuluh sebagai teknisi secara kontinum dapat dilihat seperti :

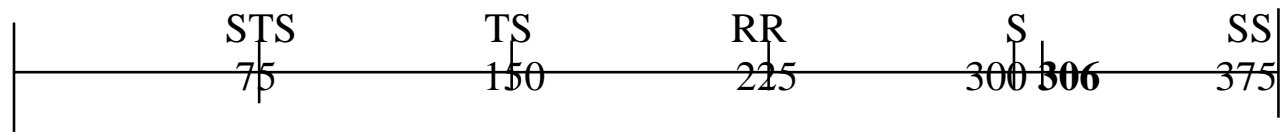

Jadi berdasarkan data di atas yang diperoleh dari 75 responden maka peran penyuluh sebagai teknisi yaitu $306 / 375 \times 100 \%=81,6$
$\%$ tergolong interval sangat setuju. Persentase kelompok responden dapat dilihat seperti :



Berdasarkan Skala Likert di atas, diperoleh peran penyuluh sebagai teknisi berdasarkan data yang diperoleh dari 75 responden, yang setuju terhadap peran penyuluh sesuai tingkat keahlian dalam memberikan demonstrasi kepada petani adalah 37 orang yang menyatakan setuju. 40 responden yang menyatakan setuju terhadap kemampuan penyuluh dalam memberikan metode dan inovasi kepada petani. Dalam hal teknisi penyuluh pertanian diharapkan mampu dalam memberikan suatu inovasi dan metode baru yang berujung pada peningkatan kualitas hasil yang diharapkan, hal ini disebabkan dari cara penyuluh menyampaikan dan memberikan demonstrasi agar lebih mudah dipahami dan diterapkan anggota kelompok karena umumnya petani akan lebih menyukai adanya praktek dibanding teori yang dismpaikan penyuluh.
Pengaruh yang sangat kuat dari kegiatan demonstrasi dapat dicapai jika hal ini dipraktekkan selanjutnya oleh anggota kelompok tani. Dengan adanya anggota kelompok yang aktif dalam kegiatan belajar mengajar maka akan sangat memudahkan untuk melakukan alih keterampialan yang diperlukan. Pada setiap adanya kunjungan penyuluh dengan kelompok tani, penyuluh harus mendorong kelompok untuk membahas hasil dari keberhasilan maupun kekurangan dalam kegiatan usahatani serta memberikan arahan untuk mengatasi kekurangan keberhasilannya tersebut.

\subsection{Penyuluh sebagai konsultan}

Data hasil penelitian terhadap responden yang menyatakan respon penyuluh sebagai konsultan sebagai berikut :

Tabel 4. Tanggapan responden terhadap peran penyuluh sebagai konsultan

\begin{tabular}{|c|c|c|c|c|c|c|}
\hline \multirow{2}{*}{$\begin{array}{c}\text { Nomor } \\
\text { Pertanyaan }\end{array}$} & \multicolumn{5}{|c|}{ Frekuensi Skor } & \multirow{2}{*}{$\begin{array}{c}\text { Jumlah responden } \\
\text { x nilai skor }\end{array}$} \\
\hline & 5 & 4 & 3 & 2 & 1 & \\
\hline 1 & 18 & 48 & 6 & 3 & 0 & 306 \\
\hline 2 & 14 & 55 & 5 & 1 & 0 & 307 \\
\hline jumlah & 32 & 103 & 11 & 4 & 0 & 613 \\
\hline \multicolumn{6}{|c|}{ Rata-rata } & 306,5 \\
\hline
\end{tabular}

Sumber : Data Primer (2016).

Berdasarkan tabel diatas diketahui frekuensi tertinggi terhadap peran penyuluh sebagai konsultan berada pada skor 4 dengan keterangan setuju pada jumlah skor 613 dengan nilai rata-rata 306,5 maka dapat diketahui peran penyuluh sebagai konsultan berada pada daerah sangat Setuju.

Jumlah skor ideal dari 2 pertanyaan = $5 \times 75=375(\mathrm{SS})$ 
Jumlah skor terendah

$=1 \times 75=75($ STS $)$

Berdasarkan data yang diperoleh dari

75 responden maka peran penyuluh sebagai konsultan secara kontinum dapat dilihat seperti :

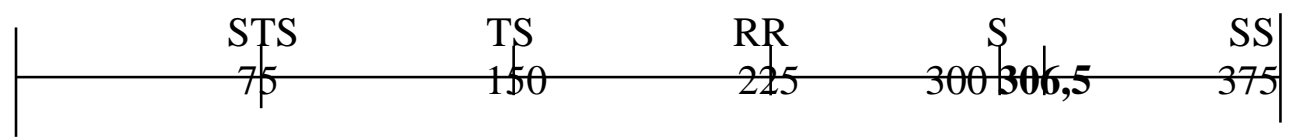

Jadi berdasarkan data di atas yang diperoleh dari 75 responden maka peran penyuluh sebagai konsultan yaitu 306,5/375 x 100\%=
$81,7 \%$ tergolong interval sangat setuju. Persentase kelompok responden dapat dilihat seperti :

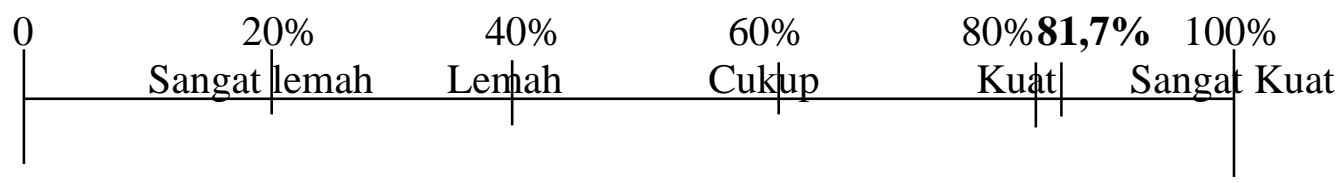

Pada skala di atas, diperoleh 75 responden setuju terhadap upaya penyuluh dalam memperkenalkan teknologi baru kepada petani dengan jumlah 48 responden yang menyatakan setuju, 55 responden yang menyatakan setuju terhadap perkenalan dengan teknologi baru yang disampaikan penyuluh kepada kelompok tani karena saat ada pertemuan dengan kelompok tani penyuluh lapangan selalu memberikan informasi dan memperkenalkan teknologi terapan. Kegiatan pertemuan kelompok selalu dihadiri seluruh anggota dan mendapat respon yang baik dari kelompok tani. Umumnya petani selalu ingin tahu tentang hal baru demi perkembangan usahatani mereka tetapi sulit untuk merubah sikap mereka tanpa adanya penerapan demonstari dari penyuluh untuk meyakinkan anggota kelompok agar bisa diaplikasikan dalam kegiatan usahatani mereka.

\section{Pengembangan kelompok Tani}

\subsection{Kegiatan Kontinyu dan Pembagian Tugas}

Berikut adalah data hasil penelitian berdasarkan tanggapan responden mengenai kegiatan dan pembagian tugas dalam kelompoknya :

Tabel 5. Tanggapan responden mengenai kegiatan dan pembagian tugas dalam kelompok tani.

\begin{tabular}{|c|c|c|c|c|c|c|}
\hline \multirow{2}{*}{$\begin{array}{c}\text { Nomor } \\
\text { Pertanyaan }\end{array}$} & \multicolumn{5}{|c|}{ Frekuensi Skor } & \multirow{2}{*}{$\begin{array}{c}\text { Jumlah responden } \\
\text { x nilai skor }\end{array}$} \\
\hline & 5 & 4 & 3 & 2 & 1 & \\
\hline 1 & 8 & 55 & 11 & 1 & 0 & 295 \\
\hline 2 & 8 & 46 & 21 & 0 & 0 & 287 \\
\hline 3 & 13 & 38 & 22 & 1 & 1 & 286 \\
\hline 4 & 16 & 35 & 18 & 6 & 0 & 284 \\
\hline jumlah & 45 & 174 & 72 & 8 & 1 & 1.152 \\
\hline \multicolumn{6}{|c|}{ Rata-rata } & 288 \\
\hline
\end{tabular}

Sumber : Data Primer (2016).

Berdasarkan tabel diatas diketahui frekuensi tertinggi terhadap pengembangan kelompok mengenai kegiatan kontinyu dan pembagian tugas dalam kelompok berada pada skor 4 dengan keterangan setuju pada jumlah skor 1.152 dengan nilai rata-rata 288 maka dapat diketahui kegiatan kontinyu dan pembagian tugas dalam kelompok berada pada daerah setuju.

Jumlah skor ideal dari 4 pertanyaan $=$ $5 \times 75=375(\mathrm{SS})$ 
Jumlah skor terendah

$=1 \times 75=75($ STS $)$

Berdasarkan data yang diperoleh dari pembagian tugas dalam kelompok secara kontinum dapat dilihat seperti :

75 responden maka kegiatan kontinyu dan

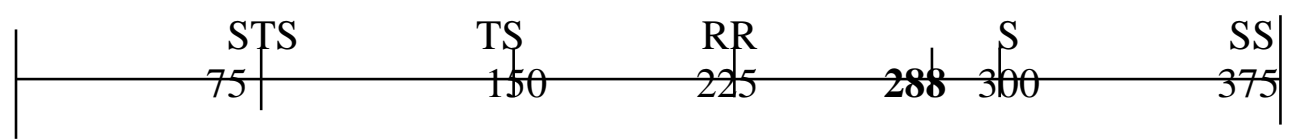

Jadi berdasarkan data di atas yang diperoleh dari 75 responden maka kegiatan kontinyu

yaitu $288 / 375 \times 100 \%=76,8 \%$ dan pembagian tugas dalam kelompok tani

tergolong interval kuat. Persentase kelompok responden dapat dilihat seperti :

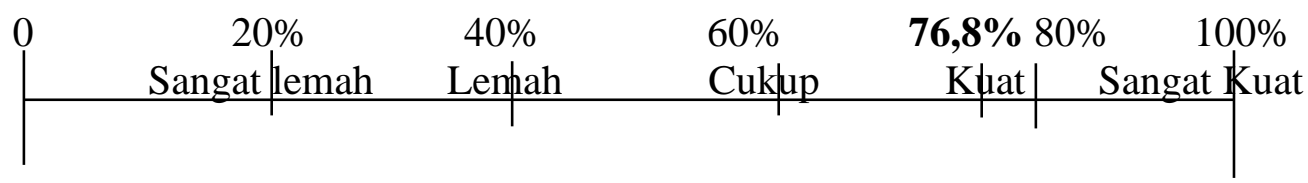

Berdasarkan skala di atas, dari 75 responden, yang setuju terhadap kegiatan rutin berupa sekolah lapang dalam kelompok tani adalah 55 responden, 46 responden yang menyetujui sistem pembagian tugas yang ada pada kelompok, 38 responden yang menyatakan keaktifan anggota kelompok tani mereka dan adanya interaksi yang baik antar anggota dalam kelompok, 35 responden yang setuju dengan adanya jumlah persensi kehadiran anggota dalam setiap pertemuan cukup baik dan dirasa kurang optimal dikarenakan hanya adanya kesibuka disetiap anggota , dan 39 responden yang menyatakan adanya pengutan kapasitas dalam kelompok tani berupa bantuan dana dan saprodi kepada petani. Hal ini terlihat dari setiap anggota yang mendapat tugas secara adil dan bergiliran, jalinan sesama anggota berjalan baik karena adanya satu tujuan yang sama dalam kelompok. Jenis penguatan setiap kelompok baik berupa bantuan dana dan saprodi tergolong tinggi karena tingkat keaktifan kelompok tani tersebut.

\subsection{Fasilitas yang Memadai}

Berdasarkan hasil penelitian mengenai sarana dan fasilitas pada masingmasing kelompok di Desa Sungai Binuang adalah sebagai berikut :

Tabel 6. Tanggapan responden mengenai sarana dan fasilitas kelompok tani

\begin{tabular}{|c|c|c|c|c|c|c|}
\hline \multirow{2}{*}{$\begin{array}{c}\text { Nomor } \\
\text { Pertanyaan }\end{array}$} & \multicolumn{5}{|c|}{ Frekuensi Skor } & \multirow{2}{*}{$\begin{array}{c}\text { Jumlah responden } \\
\text { x nilai skor }\end{array}$} \\
\hline & 5 & 4 & 3 & 2 & 1 & \\
\hline 1 & 18 & 49 & 7 & 1 & 0 & 309 \\
\hline 2 & 15 & 48 & 12 & 0 & 0 & 305 \\
\hline 3 & 20 & 12 & 16 & 1 & 0 & 302 \\
\hline jumlah & 53 & 109 & 35 & 2 & 0 & 916 \\
\hline \multicolumn{6}{|c|}{ Rata-rata } & 305,3 \\
\hline
\end{tabular}

Sumber : Data Primer 2016

Berdasarkan tabel diatas diketahui frekuensi tertinggi terhadap pengembangan kelompok mengenai fasilitas yang memadai dalam kelompok berada pada skor 4 dengan keterangan setuju pada jumlah skor 916 dengan nilai rata-rata 305,3 maka dapat diketahui fasilitas yang memadai dalam kelompok berada pada daerah sangat baik.
Jumlah skor ideal dari 3 pertanyaan $=$ $5 \times 75=375(\mathrm{SS})$

Jumlah skor terendah

$=1 \times 75=75($ STS $)$

Berdasarkan data yang diperoleh dari 75 responden maka fasilitas yan memadai dalam kelompok secara kontinum dapat dilihat seperti : 


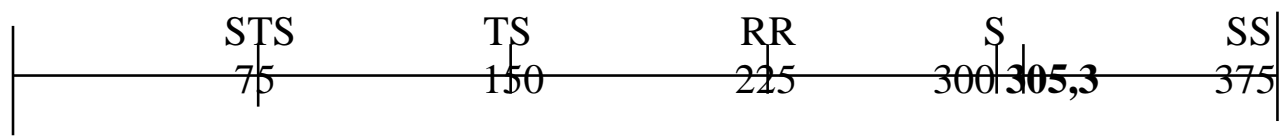

Jadi berdasarkan data di atas yang diperoleh dari 75 responden maka fasilitas yang memadai dalam kelompok tani yaitu
$305,3 / 375 \times 100 \%=81,4 \%$ tergolong interval sangat setuju. Persentase kelompok responden dapat dilihat seperti :

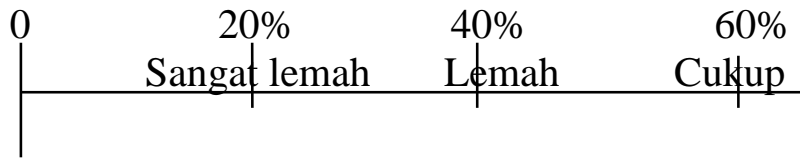

Berdasarkan skala di atas dari 75 responden yang setuju terhadap kegiatan rutin berupa sekolah lapang dalam kelompok tani, 49 responden yang menyatakan setuju dengan adanya media penyampaian informasi kepada petani yang berasal dari penyuluh, 48 responden yang menyetujui fasilitas yang digunakan penyuluh dalam kelompok tani untuk memajukan usahatani, kemudian ada 38 responden yang menyetujui fasilitas atau tempat khusus yang digunakan dalam kelompok tani yaitu bisa di rumah ketua kelompok tani dan balai desa sebagai tempat pertemuan rutin penyuluh dengan anggota

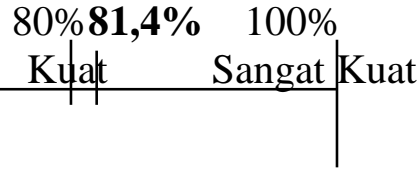

kelompok tani. Penggunaan sarana informasi dan media yang digunakan penyuluh dalam memberikan penyuluhan sudah cukup baik, walaupun belum terlalu menggunakan teknologi medern seperti halnya masih menggunakan peraga, peta singkap namun penyuluh berusaha tetap memaksimalkan kegiatan tersebut.

\subsection{Pengalaman Usahatani}

Berikut ini adalah data hasil penelitian mengenai pengalaman usahatani pada kelompok tani di Desa Sungai Binuang sebagai berikut :

Tabel 7. Tanggapan responden mengenai pengalaman usahatani pada kelompok tani

\begin{tabular}{ccccccc}
\hline Nomor & \multicolumn{9}{c}{ Frekuensi Skor } & Jumlah responden \\
Pertanyaan & 5 & 4 & 3 & 2 & 1 & x nilai skor \\
\hline 1 & 27 & 42 & 5 & 0 & 1 & 319 \\
2 & 29 & 43 & 2 & 1 & 0 & 325 \\
3 & 22 & 46 & 6 & 0 & 1 & 313 \\
\hline jumlah & 78 & 131 & 13 & 1 & 2 & 957 \\
\hline \multicolumn{7}{c}{ Rata-rata } \\
\hline
\end{tabular}

Sumber : Data Primer 2016

Berdasarkan tabel diatas diketahui frekuensi tertinggi terhadap pengembangan kelompok mengenai pengalaman usahatani dalam kelompok berada pada skor 4 dengan keterangan setuju pada jumlah skor 957 dengan nilai rata-rata 319 maka dapat diketahui pengalaman usahatani dalam kelompok berada pada daerah sangat setuju.
Jumlah skor ideal dari 3 pertanyaan $=$ $5 \times 75=375(\mathrm{SS})$

Jumlah skor terendah

$=1 \times 75=75($ STS $)$

Berdasarkan data yang diperoleh dari 75 responden maka pengalaman usahatani dalam kelompok secara kontinum dapat dilihat seperti :

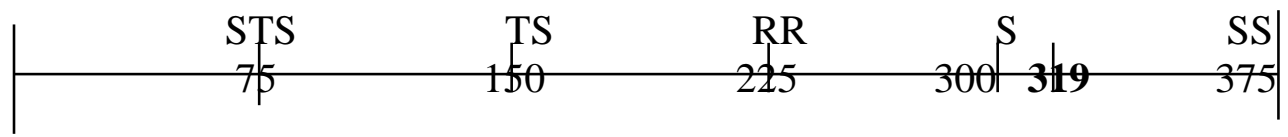

Jadi berdasarkan data di atas yang diperoleh dari 75 responden maka pengalaman usahatani dalam kelompok tani yaitu 319/375 $\mathrm{x} 100 \%=85,1 \%$ tergolong interval sangat kuat. Persentase kelompok responden dapat dilihat seperti : 


\begin{tabular}{|cccc|c|}
0 & $20 \%$ & $40 \%$ & $60 \%$ & \multicolumn{2}{c}{$80 \% \mathbf{8 5 , 1 \%} 100 \%$} \\
Sangat lemah & Lemph & Cukpp & Kulat & Sangat Kat \\
\hline & & &
\end{tabular}

Berdasarkan skala di atas, 42 responden menyatakan setuju terhadap cara penyuluh dalam memberikan pengarahan metode dan inovasi teknologi pertanian yang akan digunakan dalam kegiatan usahatani untuk lebih memudahkan petani, 43 responden yang menyatakan setuju dengan pernyataan lamanya kelompok berdiri mempengaruhi efektivitas kelompok tani mereka, 46 responden yang menyatakan setuju terhadap jalinan komunikasi yang ada dalam kelompok terhadap anggotanya, komunikasi yang baik sangat mempengaruhi perkembangan kelompok untuk menjadi lebih baik. Lamanya kelompok berdiri berpengaruh terhadap produktivitas kelompok karena semakin lama kelompok itu berdiri semakin banyak diperoleh pengalaman ataupun prestasi yang diraih suatu kelompok. Namun beberapa responden yang kurang sependapat menilai hal itu menurut mereka usia kelompok muda tetapi jika mampu bersaing dan memiliki kreativitas yang tinggi bisa di sejajarkan dengan kelompok tani diatasnya.

\subsection{Norma dan Aturan Kelompok}

Berikut adalah data hasil penelitian mengenai tanggpan responden tentang norma dan aturan kelompok pada masing-masing kelompok :

Tabel 8. Tanggapan responden mengenai norma dan aturan kelompok tani

\begin{tabular}{|c|c|c|c|c|c|c|}
\hline \multirow{2}{*}{ No. Pertanyaan } & \multicolumn{7}{|c|}{ Frekuensi Skor } & \multirow{2}{*}{$\begin{array}{c}\text { Jumlah responden } \\
\text { x nilai skor }\end{array}$} \\
\cline { 2 - 6 } & 5 & 4 & 3 & 2 & 1 & 294 \\
\hline 1 & 22 & 34 & 13 & 3 & 3 & 318 \\
\hline 2 & 29 & 39 & 3 & 4 & 0 & 275 \\
\hline 3 & 23 & 22 & 16 & 10 & 4 & 310 \\
\hline 4 & 22 & 43 & 8 & 2 & 0 & 1.197 \\
\hline jumlah & 96 & 138 & 40 & 19 & 7 & 299,2 \\
\hline
\end{tabular}

Sumber : Data Primer (2016).

Berdasarkan tabel diatas diketahui frekuensi tertinggi terhadap pengembangan kelompok mengenai norma dan aturan dalam kelompok berada pada skor 4 dengan keterangan setuju pada jumlah skor 1.197 dengan nilai rata-rata 299,2 maka dapat diketahui norma dan aturan dalam kelompok berada pada daerah setuju.
Jumlah skor ideal dari 4 pertanyaan $=$ $5 \times 75=375$ (SS)

Jumlah skor terendah

$=1 \times 75=75($ STS $)$

Berdasarkan data yang diperoleh dari 75 responden maka pengalaman usahatani dalam kelompok secara kontinum dapat dilihat seperti :

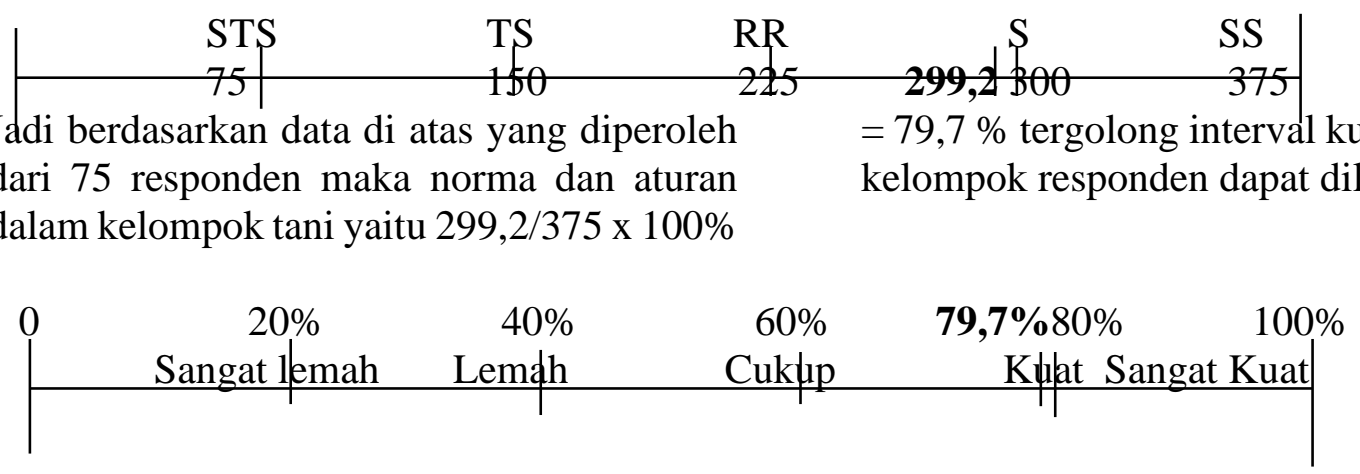


Berdasarkan skala di atas, diperoleh 34 responden menyatakan setuju terhadap norma dan tingkah laku dalam kelompok, artinya responden yang menyetujui terhadap norma dan aturan dalam kelompok tersebut adalah untuk kepentingan kelompok dan ketertiban agar setiap anggota mematuhi aturan yang ada dalam kelompok meskipun kebanyakan pada masing-masing kelompok tani di Desa Sungai Binuang belum memiliki norma dan aturan dalam kelompok secara tertulis hanya disampaikan melalui lisan saja, 39 responden yang menyatakan setuju terhadap upaya pentingnya setiap anggota menjaga nama baik kelompoknya karena menjaga nama baik kelompok merupakan suatu hal penting bagi setiap anggota untuk perkembangan kelompok kedepannya, upaya untuk menjaga nama baik kelompok tani mendapat respon yang baik, sebab menjaga nama baik kelompok merupakan tanggung jawab bersama, 22 responden yang menyatakan setuju terhadap sangsi bagi anggota yang melanggar aturan dalam kelompok karena dengan adanya aturan sangsi bagi pelanggar aturan akan

\subsection{Prestasi Kelompok}

menjadikan anggota untuk lebih memperhatikan aturan sehingga tidak ada ketimpangan status jika semua anggota mematuhi aturan dan setiap pelanggar harus mendapat sangsi, adanya sangsi bagi yang melanggar dalam kelompok kurang mendapat respon yg baik, karena sebagian anggota kelompok beranggapan seharusnya mereka yang melanggar diingatkan terlebih dahulu sebelum dikenai sangsi karena suatu kelompok lebih menyelesaikan pelanggaran secara musyawarah dan kekeluargaan, dan 43 responden yang memberikan jawaban dengan perlunya suatu penghargaan bagi anggota kelompok tani maupun pengurus kelompok yang berprestasi, artinya dengan adanya penghargaan yang diperoleh akan lebih memotivasi setiap anggota maupun pengurus untuk lebih kreativitas dalam pengembangan usahatani dan pengembangan kelompok tani mereka, karena akan lebih memotivasi antara anggota dan pengurus untuk memajukan kelompok sehingga akan membawa nama baik kelompok tani itu sendiri.

Berikut adalah data hasil penelitian tanggapan responden mengenai prestasi kelompok taninya masing-masing :

Tabel 9. Tanggapan responden mengenai prestasi kelompok tani

\begin{tabular}{ccccccc}
\hline Nomor & \multicolumn{9}{c}{ Frekuensi Skor } & Jumlah responden \\
\cline { 2 - 6 } Pertanyaan & 5 & 4 & 3 & 2 & 1 & x nilai skor \\
\hline 1 & 5 & 48 & 20 & 1 & 1 & 280 \\
2 & 4 & 41 & 22 & 6 & 2 & 266 \\
3 & 12 & 43 & 20 & 0 & 0 & 292 \\
4 & 11 & 51 & 13 & 0 & 0 & 298 \\
\hline jumlah & 32 & 183 & 75 & 7 & 3 & 1.136 \\
\hline
\end{tabular}

Sumber : Data Primer 2016

Berdasarkan tabel diatas diketahui frekuensi tertinggi terhadap pengembangan kelompok mengenai prestasi dalam kelompok berada pada skor 4 dengan keterangan baik pada jumlah skor 1.136 dengan nilai rata-rata 284 maka dapat diketahui prestasi dalam kelompok berada pada daerah setuju.

Jumlah skor ideal dari 4 pertanyaan $=$ $5 \times 75=375(\mathrm{SS})$

Jumlah skor terendah

$=1 \times 75=75($ STS $)$ 
Berdasarkan data yang diperoleh dari 75 responden maka prestasi dalam kelompok secara kontinum dapat dilihat seperti :

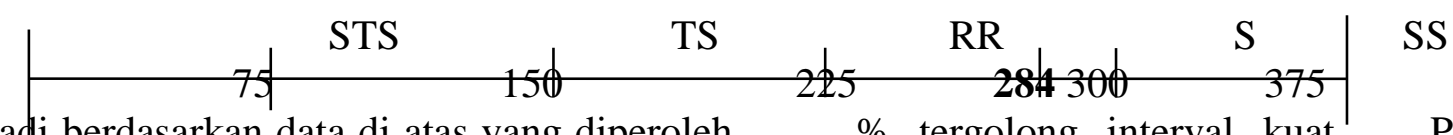

Jadi berdasarkan data di atas yang diperoleh dari 75 responden maka prestasi dalam kelompok tani yaitu 284/375 x 100\% $=75,7$

$\%$ tergolong interval kuat. Persentase kelompok responden dapat dilihat seperti :

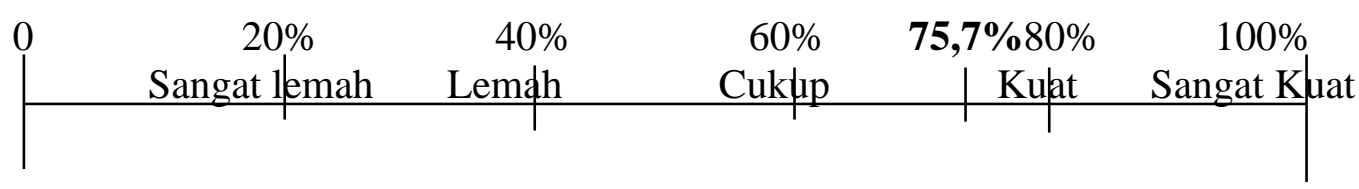

Dari skala di atas, dapat dilihat 48 responden yang menyatakan pernah mengikuti suatu perlombaan, 41 responden yang sependapat dengan adanya suatu penghargaan dari keberhasilan kelompok yang berupa hadiah dari instansi terkait karena telah memenangkan perlombaan kelompok, suatu prestasi kelompok akan membuat kelompok tersebut lebih leluasa untuk mengusahkan bantuan modal, suatu instansi akan lebih mempercayai jika suatu kelompok tersebut sudah memiliki prestasi yang baik sehingga instansi terkait dengan lembaga pertanian tersebut akan lebih mudah dalam mencairkan dana. 43 responden menyatakan setuju terhadap aktivitas kelompok tani dalam meningkatkan produktivitas hasil usahatani karena adanya bantuan penyuluh dan keberhasilan demonstrasi yang disampaikan penyuluh. $\quad 51$ responden menyatakan keberhasilan tingkat kreativitas suatu kelompok dalam kegiatan usahatani mereka, dari masing-masing kelompok tani di Desa Sungai Binung sudah merasa berupaya meningkatkan kreativitas pada kelompoknya dengan memberi masukan dan saran untuk perkembangan kelompoknya. Kelompok tani berusaha mencari terobosan baru dengan tidak hanya mengandalkan informasi dari penyuluh tetapi informasi juga bisa diperoleh dari media lainnya seperti televisi maupun lembaga lainnya.

\subsection{Kelas Kelompok}

Berikut ini adalah data hasil penelitian mengenai kelas kelompok yang berada pada masing-masing kelompok tani di Desa Sungai Binuang :

Tabel 10. Tanggapan responden mengenai kelas kelompok tani

\begin{tabular}{|c|c|c|c|c|c|c|}
\hline \multirow{2}{*}{$\begin{array}{c}\text { Nomor } \\
\text { Pertanyaan }\end{array}$} & 5 & 4 & 3 & 2 & 1 & Jumlah responden \\
\cline { 2 - 6 } & 5 nilai skor \\
\hline 1 & 16 & 47 & 11 & 1 & 0 & 303 \\
\hline jumlah & 16 & 47 & 11 & 1 & 0 & 303 \\
\hline \multicolumn{8}{|c|}{ Rata-rata } \\
\hline
\end{tabular}

Sumber : Data Primer (2016).

Berdasarkan tabel diatas diketahui frekuensi tertinggi terhadap pengembangan kelompok mengenai kelas kelompok berada pada skor 4 dengan keterangan setuju pada jumlah skor 303 dengan nilai rata-rata 303 maka dapat diketahui kelas kelompok berada pada daerah sangat setuju.
Jumlah skor ideal dari 1 pertanyaan $=$ $5 \times 75=375$ (SS)

Jumlah skor terendah $=1 \times 75=75($ STS $)$

Berdasarkan data yang diperoleh dari 75 responden maka prestasi dalam kelompok secara kontinum dapat dilihat seperti : 


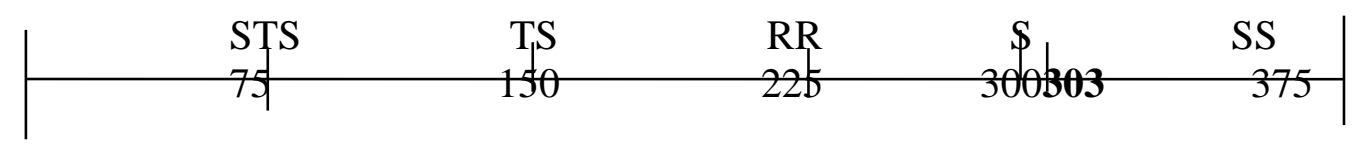

Jadi berdasarkan data di atas yang diperoleh dari 75 responden maka kelas kelompok tani yaitu $303 / 375 \times 100 \%=80,8 \%$ tergolong interval sangat kuat. Persentase kelompok responden dapat dilihat seperti :

\begin{tabular}{|c|c|c|c|}
\hline $20 \%$ & $40 \%$ & $60 \%$ & $80 \% \mathbf{8 0 , 8 \%}$ \\
\hline Sangat lemah & Lemah & Cukup & Kulat Sangat Kuat \\
\hline
\end{tabular}

Berdasarkan skala di atas 47 responden yang menyatakan bahwa ke 3 kelompok tani yang ada di desa Sungai Binuang yaitu kelompok tani Matang Sawo, Manalagi dan Nusa Indah berstatus kelas lanjut yang artinya kelompok tani dengan kelas lanjut merupakan tingkatan kelas yang lebih tinggi dimana kelompok tani sudah melakukan kegiatan perencanaan meskipun masih terbatas, dengan mempunyai nilai 251 sampai dengan 500 .

\subsection{Kewenangan dan Kompetensi Penyuluh Pertanian}

Dari hasil penelitian yang telah dilakukan di Desa Sungai Binuang bahwa kewenangan penyuluh pertanian tidak mutlak dilaksanakan oleh kelompok karena segala keputusan yang ada dikelompok tani kemudian dimusyawarahkan dan diputuskan oleh anggota. Penyuluh hanya menyampaikan informasi kepada kelompok masing-masing pada setiap pertemuan kelompok tentang apa saja yang berkaitan dengan kelompok.

Kompetensi penyuluh merupakan kemampuan dan kemauan yang kuat dari seorang penyuluh dalam upaya pengembangan dan kemajuan kelompok. Dibutuhkan perubahan-perubahan mendasar dalam dunia pertanian karena sebagian besar perubahan memerlukan petani-petani yang kompeten yang dapat memberikan produktivitas hasil usaha kelompok. Dari hasil penelitian yang dilakukan pada penyuluh di Desa Sungai Binuang dapat disimpulkan bahwa penyuluh sangat berkompeten terhadap kelompok tani. Hal ini dapat diketahui dari penyuluh dalam memberikan bimbingan dan segala bentuk kegiatan mengenai usahatani seperti halnya kegiatan sekolah lapang, praktek percobaan dilapangan, bantuan dana dan lainnya. Cara ini sangat membantu kelompok dalam pengembangan kegiatan usahatani dalam kelompoknya.

Penyuluh pertanian seharusnya dapat banyak belajar dan mencari pengalaman dari pengalaman petani yang berhasil serta menggunakan informasi tersebut untuk mengolah pesan-pesan penyuluhan yang ingin disampaikan pada situasi setempat. Para penyuluh dapat mendiskusikan pada berbagai kesempatan program penyuluhan dan menyesuaikan rencana penyuluhan kedepan atas dasar gagasan-gagasan para petani. Penyuluh pertanian adalah orang yang memiliki kompetensi yang tinggi yang mampu bertahan pada iklim baru dan keberhasilan penyuluh akan meningkatkan pendapatan petani. Dari peningkatan pendapatan petani akan meningkatkan kegiatan perekonomian daerah yang nantinya meningkatkan pendapatan asli daerah masyarakat wilayah tersebut. Masarakat petani diharapkan mampu meningkatkan kemampuannya dalam penerapan pendekatan agribisnis yang berkelanjutan sehingga petani mampu menjadi mitra sejajar dengan pemerintah dan pengusaha.

Sektor pertanian harus tetap hidup dan dikembangkan untuk menghasilkan sebagai tulang punggung perekonomian nasional, permasalahan dibidang penyuluhan yang sangat mendasar seiring dengan perkembangan informasi dan tekhnologi adalah kualitas sumberdaya penyuluh yang dipandang perlu untuk terus ditingkatkan. Tanpa penyuluh pertanian, suatu kelompok tani tidak mungkin mendapatkan kekompakkan dilapangan karena petani mempunyai ego masing-masing. Dengan adanya kehadiran penyuluh dilapangan, 
petani akan lebih kompak karena pada dasarnya keberhasilan petani adalah kebanggaan penyuluh juga.

\section{KESIMPULAN}

Peran penyuluh pertanian dalam pengembangan kelompok tani dari BPK Kecamatan Haur Gading yang bertugas diwilayah Desa Sungai Binuang Kecamatan Haur Gading, dalam usaha pengembangan kelompok tani sudah menjalankan tugasnya. Penyuluh pertanian aktif menghadiri pertemuan yang diadakan kelompok tani, penyuluh pertanian aktif menyampaikan informasi dan teknologi usahatani kepada kelompok tani, penyuluh membimbing dan memfasilitasi petani. Kegiatan penyuluhan di Desa Sungai Binuang Kecamatan Haur Gading sudah berjalan optimal, dengan adanya kegiatan yang diikuti kelompok tani sehingga dapat menambah wawasan petani maupun kelompok untuk mengembangkan usahataninya. Kewenangan dan kompetensi penyuluh pertanian belum bisa dilakukan secara optimal karena seorang penyuluh pertanian hanya berwenang mengarahkan dan memberi masukan atas segala keputusan yang diambil dalam suatu kelompok, namun tidak mutlak harus dilakukan oleh kelompok sebab keputusan berlaku ditangan anggota kelompok.

\section{DAFTAR PUSTAKA}

Balai Penyuluhan Kecamatan Haur Gading Kabupaten Hulu Sungai Utara. 2013. Data Kelompok Tani Kecamatan Haur Gading 2013. BPK Kecamatan Haur Gading. Amuntai.

Hawkins dan Van Den Ban. 1999. Penyuluhan Pertanian. Kanisus. Yogyakarta.

Mardikanto, Totok. 2009. Membangun Pertanian Modern. Sebelas Maret University Press. Surakarta.

Mushero, Heroni. 2008. Pemberdayaan Petani Melalui Gabungan Kelompok Tani (GAPOKTAN).http://heronimushero .wordpress.com/2008/03/05/pember dayaan-petani-melalui-gabungankelompok-tani-gapoktan/. Diakses pada tanggal 12 Februari 2016.

Sastraatmadja, Entang. 1993. Penyuluhan Pertanian: Falsafah, Masalah dan Strategi. Penerbit Alumni. Bandung.

Setiana, L. 2005. Teknik Penyuluhan dan Pemberdayaan Masyarakat. Ghalia indonesia. Bogor. 